Article

\title{
Snake Venom Hemotoxic Enzymes: Biochemical Comparison between Crotalus Species from Central Mexico
}

\author{
Octavio Roldán-Padrón ${ }^{1}$, José Luis Castro-Guillén ${ }^{2}$, José Alejandro García-Arredondo ${ }^{3}$, \\ Martha Sandra Cruz-Pérez ${ }^{1}$, Luis Fernando Díaz-Peña ${ }^{3}$, Carlos Saldaña ${ }^{1}$, \\ Alejandro Blanco-Labra ${ }^{2, *}$ and Teresa García-Gasca ${ }^{1, *}$
}

1 Universidad Autónoma de Querétaro, Facultad de Ciencias Naturales, Avenida de las Ciencias S/N, Juriquilla, Querétaro 76230, México; octavio.roldan@uaq.mx (O.R.-P.); martha.sandra.cruz@uaq.mx (M.S.C.-P.); carlos.saldana@uaq.mx (C.S.)

2 Centro de Investigación y de Estudios Avanzados del IPN, Unidad Irapuato, Irapuato, Guanajuato 36824, México; tekk.el.527@gmail.com

3 Universidad Autónoma de Querétaro, Facultad de Química, Cerro de las Campanas S/N, Centro Universitario, Querétaro 76010, México; alejandro.gr@uaq.mx (J.A.G.-A.); fer_diazp@hotmail.com (L.F.D.-P.)

* Correspondence: alejandroblancolabra@gmail.com (A.B.-L.); tggasca@uaq.edu.mx (T.G.-G.); Tel.: +52-(462)-62396-00 (A.B.-L.); +52-(442)-1921200 (ext. 5308) (T.G.-G.); Fax: +52-(462)-624-58-46 (A.B.-L.)

Received: 10 February 2019; Accepted: 10 April 2019; Published: 16 April 2019

\begin{abstract}
Snakebite envenoming is a serious medical problem in different areas of the world. In Latin America, the major prevalence is due to snakes of the family Viperidae, where rattlesnakes (Crotalus) are included. They produce hemotoxic venom which causes bleeding, tissue degradation and necrosis. Each venom has several enzymatic activities, producing different effects in the envenoming, doing its clinical effects difficult to study. Comparison between venom molecules is also difficult when different techniques are used, and therefore, their identification/characterization using the same methodology is necessary. In this work, a general biochemical characterization in snake venom of serine proteases (SVSP), phospholipases $\mathrm{A}_{2}\left(\mathrm{PLA}_{2}\right)$, metalloproteases (SVMP) and hyaluronidases $(\mathrm{SVH})$ of Crotalus aquilus (Ca), Crotalus polystictus (Cp) and Crotalus molossus nigrescens ( $\mathrm{Cmn}$ ) was done. Differences in protein pattern, enzyme content and enzymatic activities were observed. All the venoms showed high PLA $\mathrm{P}_{2}$ activity, high molecular weight SVSP, and a wide variety of SVMP and SVH forms. Ca and Cp showed the highest enzymatic activities of SVMP and SVSP trypsin-like and chymotrypsin-like, whereas $\mathrm{Cmn}$ showed the highest SVH and similar $\mathrm{PLA}_{2}$ activity with Ca. All the venoms showed peptides with similar molecular weight to crotamine-like myotoxins. No previous biochemical characterization of $C$. aquilus has been reported and there are no previous analyses that include these four protein families in these Crotalus venoms.
\end{abstract}

Keywords: Crotalus; snake venom; phospholipases $\mathrm{A}_{2}$; hyaluronidases; metalloproteases; serine proteases

\section{Introduction}

Snakebite envenoming is a serious medical problem and yet some of the venom components have not been characterized. It is presently affecting people mainly from rural areas of tropical and subtropical regions of the world, mainly Asia, Africa, and Latin America. Annually, up to 5.4 million people are bitten by venomous snakes which cause between 20,000-94,000 deaths [1-3]. Snakes of the Viperidae family are responsible for a high number of bites in Latin America countries [4]. This 
family includes the Crotalus species (rattlesnakes) [2,5-7] that contain four main hemotoxic enzyme families: snake venom serine proteases (SVSP), snake venom hyaluronidases (SVH), snake venom metalloproteases (SVMP), and phospholipases $\mathrm{A}_{2}\left(\mathrm{PLA}_{2}\right)[8,9]$. Although SVH have been reported, there is little information available $[10,11]$. The clinical effects of these type of venoms include inflammation, hemorrhaging at systemic and local levels, edema, tissue degradation, and necrosis [12]. The high variability in venom composition, which can produce different pathophysiological effects, as well as the synergistic and antagonistic effects of their components, make the complex events occurring during envenoming difficult to determine $[13,14]$. Therefore, the characterization and purification of venom components are key strategies in toxicology to understand the symptoms that occur during envenoming $[9,15,16]$, however, only a few toxins have been completely examined [17]. In this work, venom from three Crotalus species was analyzed. C. molossus nigrescens $(\mathrm{Cmn})$ is found in the Mexican highlands between Chihuahua and Oaxaca [18], C. polystictus (Cp) and C. aquilus (Ca) endemic species from central Mexico [19,20].

The enzymatic composition of Crotalus molossus molossus venom has already been studied, (serine proteases, metalloproteases and phospholipases), based mainly on the molecular weight determined by SDS-PAGE [21]. For Cmn, a thrombin-like serine protease was determined [22] and, by an analysis of the ontogenetic variation, the presence of crotamine, SVSP, SVMP, proteolytic, coagulant and fibrinogenolytic activities were reported by reverse phase high performance liquid chromatography (RP-HPLC) and western blot assays [23]. In the case of Cp, there is one characterization work by shotgun proteomic by LC-MS/MS and enzymatic activities determination for SVMP, SVSP, phosphodiesterase and L-amino acid oxidases (LAAO) [24]. However, for Ca only the protease activity has been identified [25] and there is not enough data about this venom composition. Presently, no previous biochemical characterization that includes the four enzyme families has been reported. Attention must be given to the high variability due to differences in the way samples are obtained, their preservation, type and concentration of substrates used to determine their activities, as well as the methodology used since these factors can influence the results [26,27]. In this work, we show novel data for the biochemical identification, enzyme activities and HPLC analysis for SVSP, PLA 2 , SVMP and SVH from the three snake Crotalus venoms using the same methodology in each case. The comparison between them can contribute to the development of specific snake bite treatments [21].

\section{Results and Discussion}

\subsection{SDS-PAGE Protein Banding Pattern}

Snake venoms of the Viperidae family consist of a complex mixture of proteins (up to 100 proteins), including different types of protein families [28]. The protein banding patterns of $\mathrm{Ca}, \mathrm{Cp}$ and $\mathrm{Cmn}$ venoms under reducing and non-reducing conditions showed proteins with a broad range of molecular weights ranging from 6 to $180 \mathrm{kDa}$ (Figure 1) with similarities in their protein pattern, but with some different protein bands, mainly in the range of 50 and $15 \mathrm{kDa}$. These differences have been observed in other snake venoms [14,29]. The protein patterns banding for $\mathrm{Cmn}$ and $\mathrm{Cp}$ are similar to previously reported data $[23,30]$. For Cp, LAAO, an abundant enzyme family related to the presence of yellow color in snake venoms [30,31] has been reported near $50 \mathrm{kDa}$ [24]. In this work, all the venoms were yellow and showed a band of similar molecular weight that could correspond this enzyme (Figure 1), however, more studies and enzymatic activities determination for LAAO in these species, are still necessary to confirm its presence. For $\mathrm{Cmn}$ a $10 \mathrm{kDa}$ crotamine-like myotoxin has been reported [23]. In this study, all the venoms showed protein bands in this molecular weight. 


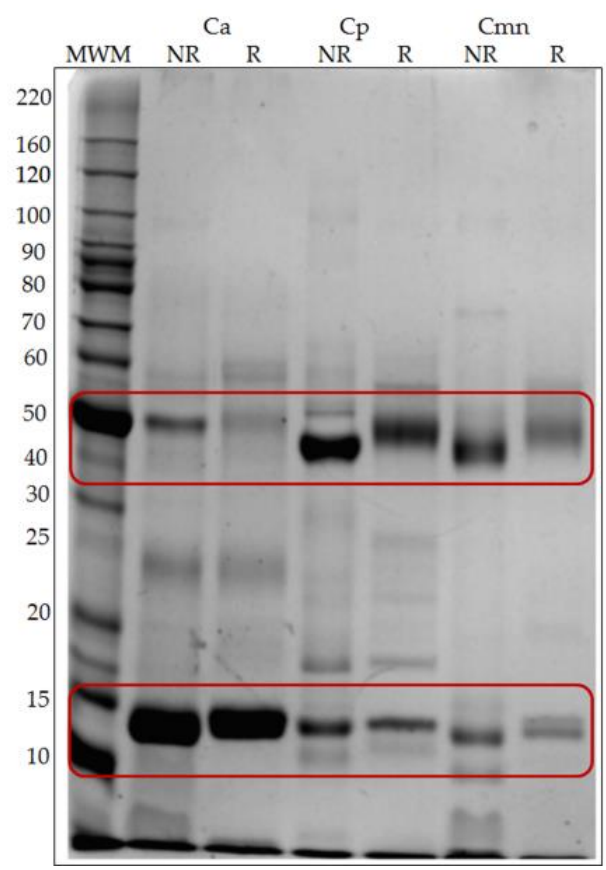

Figure 1. Sodium dodecyl sulfate polyacrylamide gel electrophoresis (SDS-PAGE) protein banding pattern for C. aquilus (Ca), C. polystictus $(\mathrm{Cp})$ and C. molossus nigrescens $(\mathrm{Cmn})$ venoms. Twenty micrograms of lyophilized venoms were analyzed by non-reducing (NR) and reducing conditions (R) in $10 \%$ polyacrylamide gels. MWM: molecular weight markers $(\mathrm{kDa})$. Variation in the bands with molecular weight $\sim 15 \mathrm{kDa}$ and $\sim 50 \mathrm{kDa}$ are marked with red boxes.

\subsection{Zymography and Enzymatic Activities for Serine Proteases}

Although SVSP has been reported in the range of 25-76 kDa [32], we detected bands in a broader range, between 15 and $95 \mathrm{kDa}$ for trypsin-like (BApNA substrate) and 40 and $80 \mathrm{kDa}$ for chymotrypsin-like (SAAFpNA substrate) serine proteases for $\mathrm{Ca}, \mathrm{Cp}$ and $\mathrm{Cmn}$ venoms (Figure 2). These differences in molecular weight may be related to differences in their glycosylation patterns [33]. Chymotrypsin-like enzymes were less abundant than trypsin-like proteases, where BApNA substrate could also be recognized in general by serine proteases, such as thrombin-like and trypsin-like serine proteases [34]; these proteases are associated with the activation of metalloproteases zymogens [35]. $\mathrm{Ca}$ and $\mathrm{Cmn}$ venoms showed differences in SVSP trypsin-like in the range of $70 \mathrm{kDa}$, whereas for $\mathrm{Cp}$ venom did not appear to show activity in this molecular weight range. $\mathrm{Cmn}$ and $\mathrm{Cp}$ venoms also showed three proteases bands in a range of 14 to $25 \mathrm{kDa}$ that were absent in Ca venom. For SVSP chymotrypsin-like proteases, Ca venom show two proteases bands, 40 and $80 \mathrm{kDa}$, whereas $\mathrm{Cmn}$ venom did not show the second one and in $\mathrm{Cp}$ venom both bands were absent. Some of the protein bands appear as weak bands in SDS-PAGE corresponding to trypsin-like proteases (Figure 1), which were charged with the same protein amount, this could be due to the difference in sensitivity of the technics, since zymography is a more sensitive method [36]. These protein bands can also be observed in the SDS-PAGE pattern banding and SDS-PAGE used for the chymotrypsin-like activity, which was done with a higher amount of venom protein $(100 \mu \mathrm{g})$ (Figure 2).

Serine protease activity using BApNA substrate was higher than using SAAFpNA and elastase substrates in each case. Substrates with arginine in the P1 position, such as BApNA, can be hydrolyzed by trypsin-like and thrombin-like enzymes which are abundant components in snake venom [34]. Trypsin-like and chymotrypsin-like activities for $\mathrm{Cp}$ venom showed the highest values, while $\mathrm{Ca}$ and $\mathrm{Cmn}$ venoms showed the same activity. For elastase-like activity, Ca venom presented the lowest activity (Figure 3). 

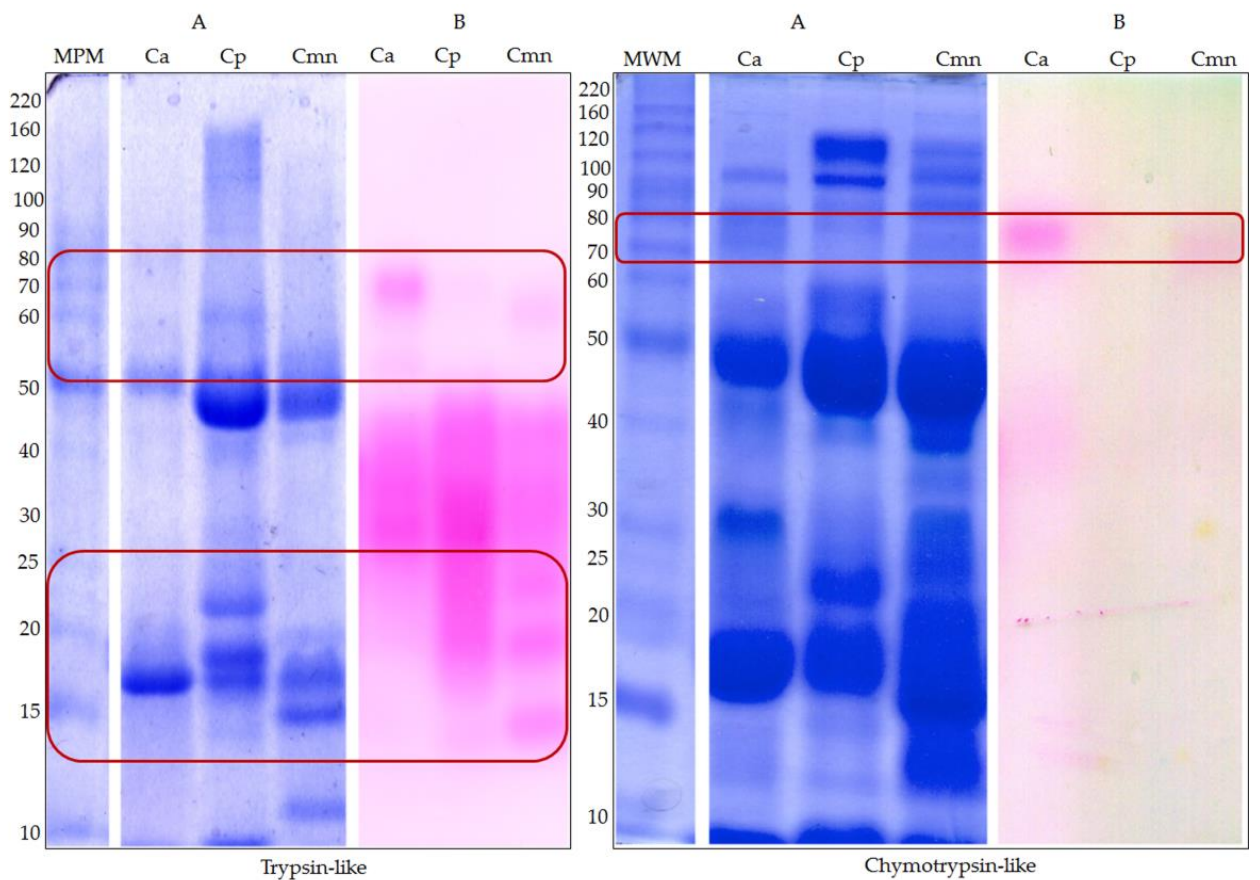

Figure 2. Protein pattern by SDS-PAGE, and Serine proteases zymography for C. aquilus (Ca), C. polystictus (Cp) and C. molossus nigrescens (Cmn) venoms. (A) 10\% SDS-PAGE and (B) zymography. Trypsin-like zymography was performed using $50 \mu \mathrm{g}$ of venom samples protein with BApNA substrate. Chymotrypsin-like zymography was determined using $100 \mu \mathrm{g}$ of venom protein with SAAFpNA substrate. After electrophoresis, a cellulose membrane with each serine protease was placed on top of the gel and incubated for $5 \mathrm{~h}$ and $2.5 \mathrm{~h}$ at $37^{\circ} \mathrm{C}$, respectively. MWM: molecular weight markers (kDa). Variability in proteases bands is marked with red boxes.
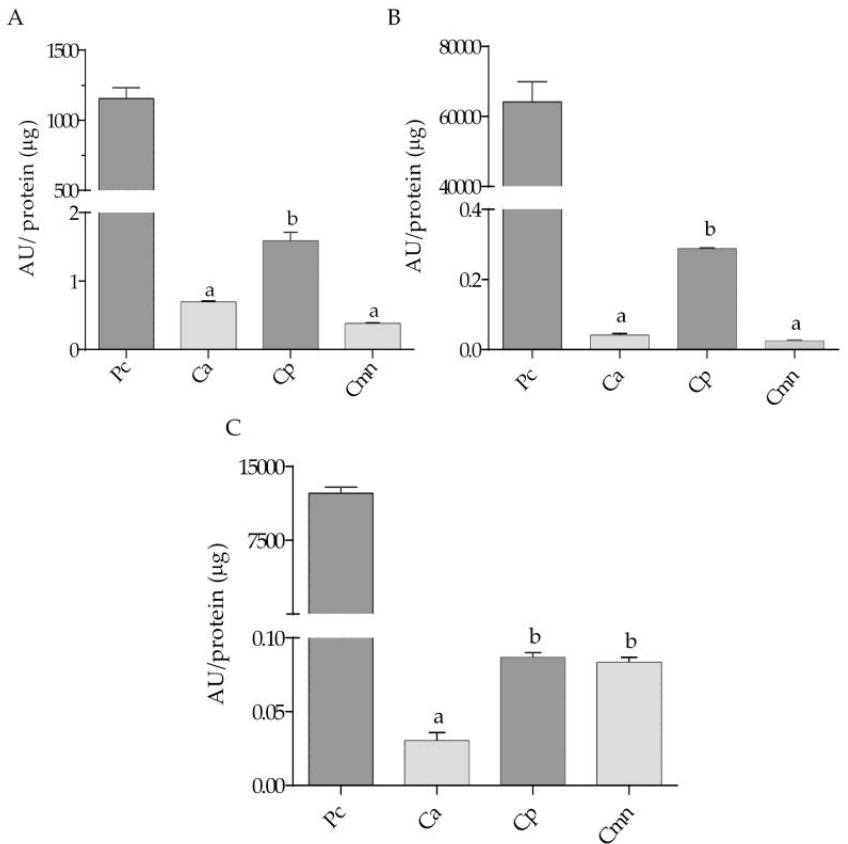

Figure 3. Snake venom serine proteases activities for C. aquilus (Ca), C. polystictus (Cp) and C. molossus nigrescens (Cmn) venoms. (A) Trypsin-like proteases, using bovine trypsin as positive control; (B) chymotrypsin-like proteases, using bovine chymotrypsin as positive control; (C) elastase-like proteases, using porcine elastase as a positive control. Enzymatic activity expressed in activity units $(\mathrm{AU} / \mu \mathrm{g})$. Small letters show significant differences (Tukey $p<0.05$ ) between samples for each enzyme, positive controls $(\mathrm{Pc})$ were not compared. 


\subsection{Zymography and Gelatinolytic/Caseinolytic Activities}

In previous works, the proteolytic activity of SVMP was analyzed using the basement membrane's protein degradation assay [16,37]. These enzymes can hydrolyze fibronectin, laminin, type IV collagen, and types I, III, and V gelatin [38]. The proteolytic activity of $\mathrm{Ca}, \mathrm{Cp}$, and $\mathrm{Cmn}$ venoms in gelatin zymography (Figure 4A) and the proteolytic activity using casein as substrate are shown (Figure 4B). $\mathrm{Ca}$ venom presented the highest caseinolytic activity followed by $\mathrm{Cp}$ and $\mathrm{Cmn}$ venoms. When the same activity was analyzed in the presence of EDTA, Ca and Cmn venoms showed no activity, while Cp venom kept up 40\% activity, probably due to the presence of some serine proteases that recognize casein as substrate, as reported by Krogdahl and Holm (1983) for serine proteases of mammalians and birds [39]. These results are consistent with the highest trypsin and chymotrypsin-like serine protease activities showed by $\mathrm{Cp}$ venom. The decrease in all venoms activity by the chelating effect of EDTA indicates that the main proteolytic activity using casein as a substrate corresponds to metalloproteases. Gelatin zymography results showed that $\mathrm{Ca}$ venom presented the highest number of proteases, followed by $\mathrm{Cmn}$ and $\mathrm{Cp}$ venoms.

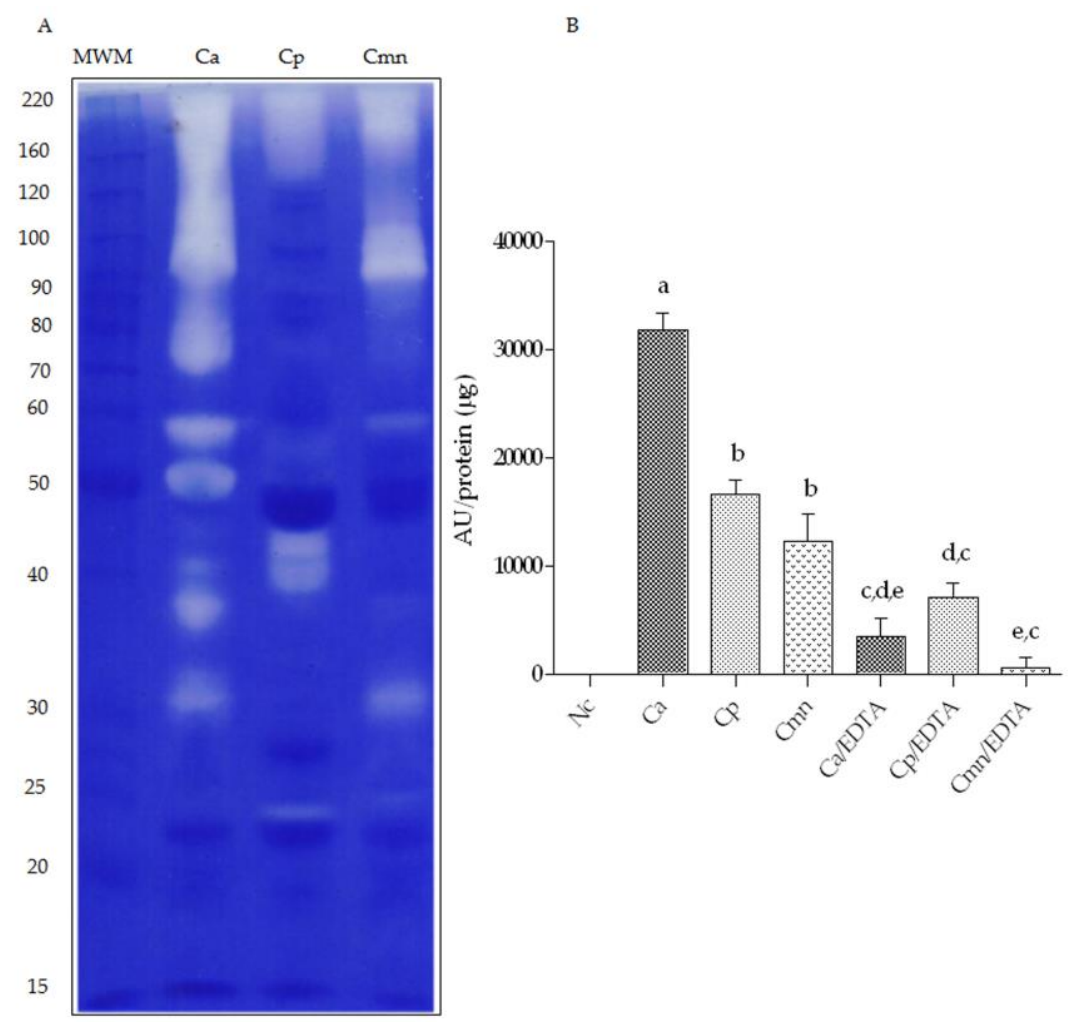

Figure 4. Gelatin zymography in $10 \%$ polyacrylamide gels and proteolytic activity using casein substrate. (A) Ten micrograms of venom protein from C. aquilus (Ca), Crotalus polystictus (Cp) and C. molossus nigrescens ( $\mathrm{Cmn}$ ) were incubated after electrophoresis for $2.5 \mathrm{~h}$ at $37^{\circ} \mathrm{C}$. MWM-molecular weight markers (kDa). (B) Proteolytic activity of $100 \mu \mathrm{g}$ of venom samples in the presence/absence of $50 \mathrm{mM}$ EDTA incubated with casein as a substrate for $2.5 \mathrm{~h}$ at $37^{\circ} \mathrm{C}$. Negative control (Nc). Small letters $(\mathrm{a}, \mathrm{b}, \mathrm{c}, \mathrm{d}, \mathrm{e})$ show statistical difference (Tukey $p<0.05)$. Variability in proteases bands is marked with red boxes. Small letters show significant differences (Tukey $p<0.05$ ) between samples, either with or without ethylendiaminetetraacetic acid (EDTA).

Since all SVMP activity are zinc-dependent [40], their presence was confirmed in gelatin zymography using EDTA (Figure 5). The SVMP of $\mathrm{Ca}, \mathrm{Cp}$ and $\mathrm{Cmn}$ venoms corresponded to protein bands between 30 and $200 \mathrm{kDa}$, which were inactivated by EDTA at concentrations between 10 and $50 \mathrm{mM}$. The activity of most proteases in $\mathrm{Cp}$ venom was suppressed under these conditions, however, some proteases of MW of 40, 50, and $70 \mathrm{kDa}$ remained active for Ca venom, and, other 
proteases of 70 and $90 \mathrm{kDa}$ remained active for $\mathrm{Cmn}$ venom. These bands could correspond to thrombin-like enzymes since some of them can hydrolyze gelatin [41], however, the majority of serine proteases (detected by zymography) for $\mathrm{Cp}$, and bellow $25 \mathrm{kDa}$ for Ca and Cmn, showed no gelatinolytic activity.
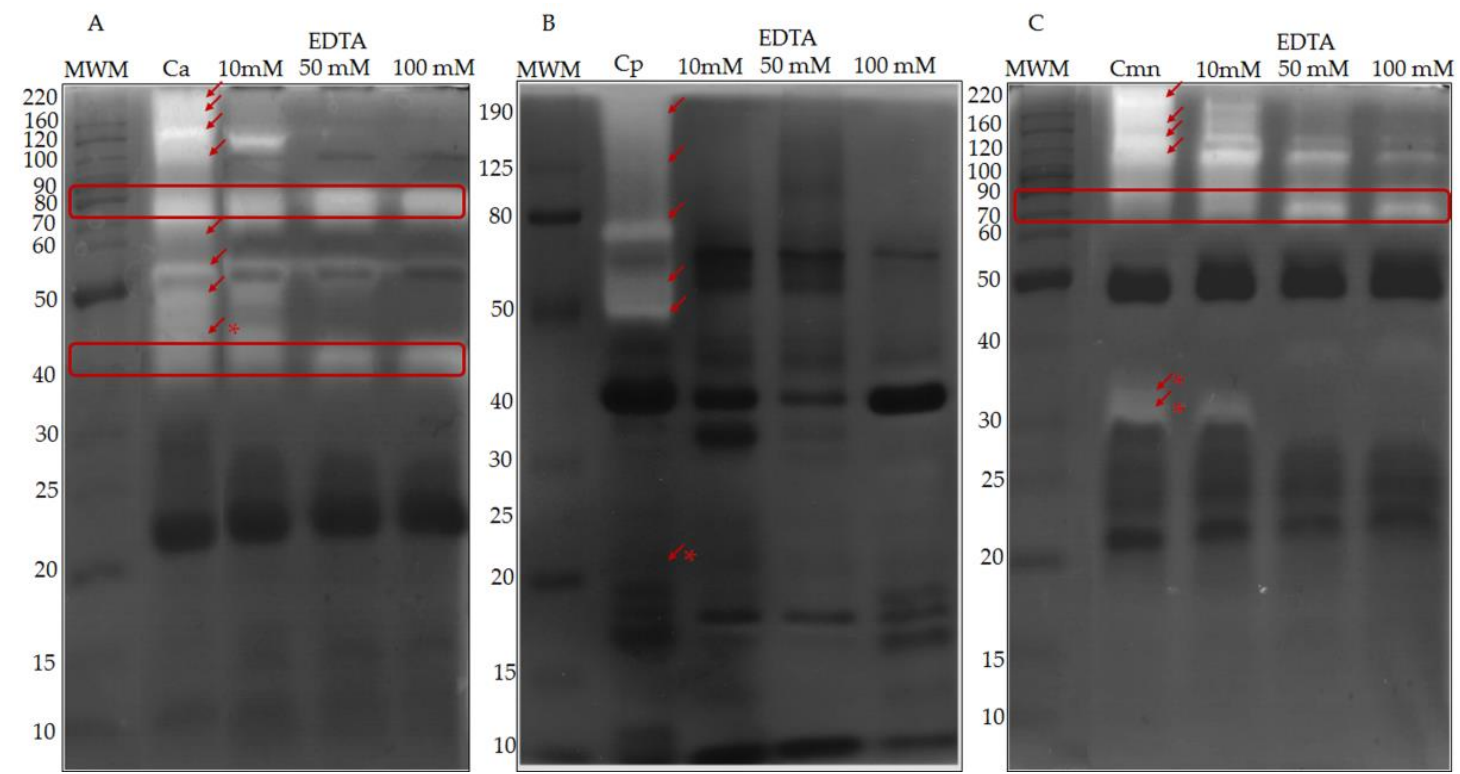

Figure 5. Zymography in 10\% polyacrylamide gels co-polymerized with gelatin. Ten microgram of venom protein from (A) C. aquilus (Ca), (B) C. polystictus (Cp), and (C) C. molossus nigrescens (Cmn). In addition, $10 \mu \mathrm{g}$ of the same samples were tested with 10,50 and $100 \mathrm{mM}$ EDTA in gels that were incubated after electrophoresis for $2.5 \mathrm{~h}$ at $37^{\circ} \mathrm{C}$. Red arrows indicate inhibition of snake venom metalloproteases (SVMP) by EDTA, red asterisk $\left({ }^{*}\right)$ show bands not shared between the venoms, red boxes show proteases bands with gelatinolytic activity unaffected by EDTA. Molecular weight markers (MWM) in kDa.

Previous reports by Sánchez et al. (2001) and Chen and Rael (1997) showed the presence of two metalloproteases, one of $26 \mathrm{kDa}$ and another of $25 \mathrm{kDa}$, respectively [42,43]. Ramírez (1990) reported the isolation of one protease and one thrombin-like serine protease in Cmn venom. In addition, for this species and for Cp venoms, Mackessy (2010) described the presence of SVMP with MWs of 21 and $45 \mathrm{kDa}[21,22,44]$. Our results show that Cmn venom has at least six SVMP bands of 30, 120, and $170 \mathrm{kDa}$ and two of $200 \mathrm{kDa}$, indicating differences with the C. molossus molossus venom. Additionally, SVMP of 20, 50, 60, 75, 125 and $190 \mathrm{kDa}$ bands were identified in Cp venom, with some differences in comparison with previous works that report SVMP of 20 and $50 \mathrm{kDa}$ [24] by mass spectrometry. In the case of Ca venom, no previous reports for these proteases were found.

SVMP and SVSP have been reported as the main proteases for some Viperidae venoms $[8,44,45]$. For $\mathrm{Ca}, \mathrm{Cp}$, and $\mathrm{Cmn}$ venoms, most of the high molecular weight proteases corresponded to those two types of enzymes, probably due to the presence of homodimers or heterodimer oligomers, which have been reported for SVMP of the class P-III, PLA 2 and LAAO [46]. The identification of SVMP and SVSP (thrombin-like) in snake venoms is of particular interest since both activities have synergistic effects causing heavy bleeding $[47,48]$. Cp and Ca venoms show high activities of those type of proteases, similar and even higher than the activity for $\mathrm{Cmn}$ venom, which has been described as highly hemorrhagic and hemolytic [49,50]. For Cmn venom, at least two SVSP have been reported as the main compounds associated with the venom's lethality [23]. 


\subsection{Zymography and Enzymatic Activities of Phospholipases $A_{2}$}

Zymography of $\mathrm{Cmn}$ shows two protein bands (10 and $15 \mathrm{kDa}$ ), similar to the proteins previously reported by mass spectrometry in C. molossus molossus venom, 15.7 and $17 \mathrm{kDa}$ [51] and 13.7 and $13.6 \mathrm{kDa}$ [52]. For $\mathrm{Ca}$ and $\mathrm{Cp}$ venoms, $12 \mathrm{kDa}$ and $13 \mathrm{kDa}$ bands for $\mathrm{PLA}_{2}$ were found, respectively. These molecular weights were within the range reported for snake venom PLA $_{2}$ (13-18 kDa) [53]. In this study, the protein bands for $\mathrm{PLA}_{2}$ for $\mathrm{Ca}, \mathrm{Cp}$, and $\mathrm{Cmn}$ venoms were different, however, the activity values of $P L A_{2}$ for $C a$ and $C m n$ venoms were similar, whereas for $C p$ venom this enzymatic activity was the lowest. Compared with the positive control (bee $\mathrm{PLA}_{2}$ ), all the venoms showed higher enzymatic activity (Figure 6), which could be related to the myotoxic damage to muscle fibers caused by hemotoxic venoms [54]. For Cmn venom, the hemolytic effect has been related to the PLA associated with plasmatic membrane degradation [50].

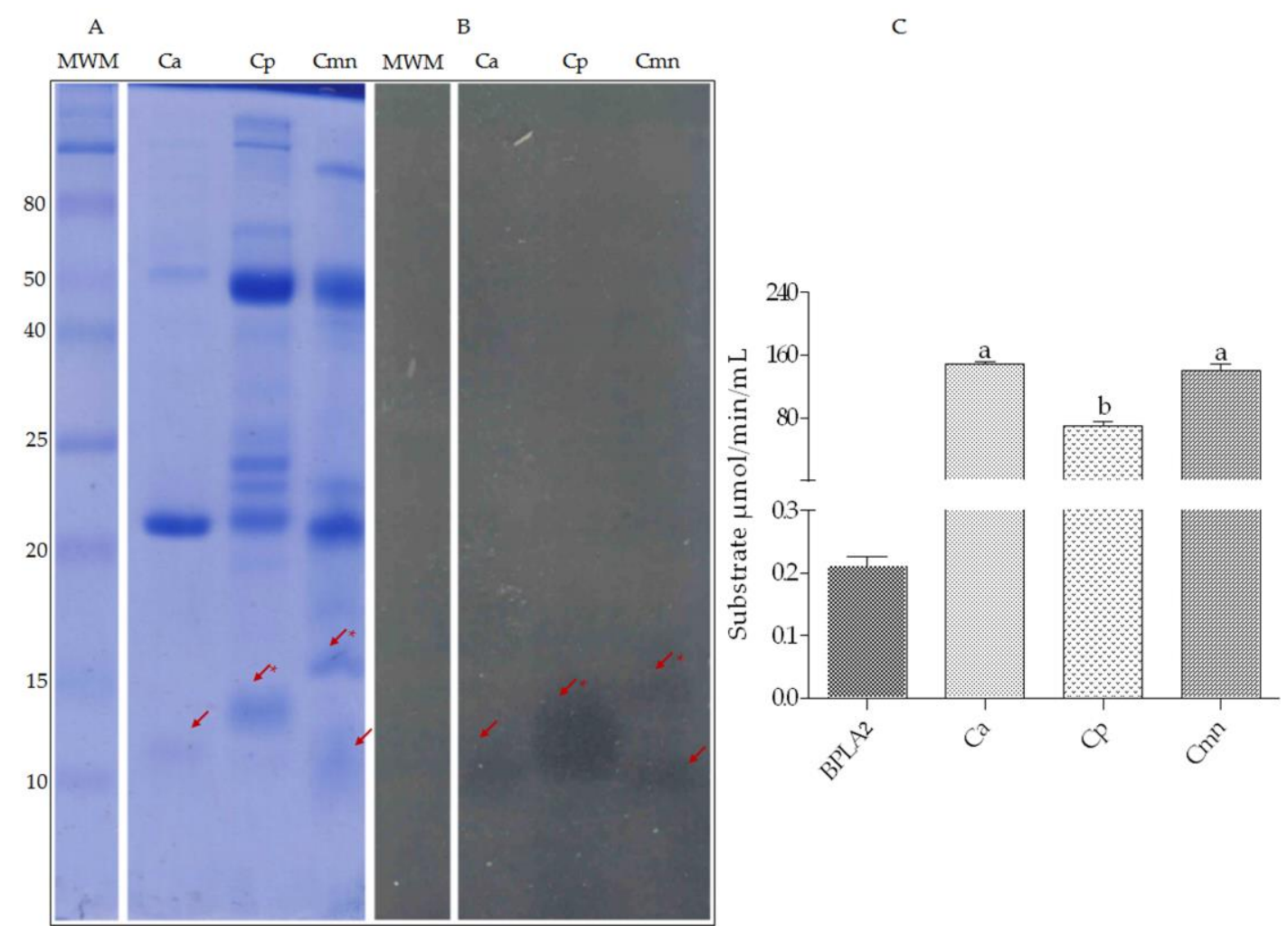

Figure 6. Zymography and enzymatic activity of PLA2. (A) 12\% SDS-PAGE, (B) 4\% agarose-egg yolk co-polymerized gel zymography using $20 \mu \mathrm{g}$ of protein from C. aquilus (Ca), C. polystictus (Cp), and C. molossus nigrescens (Cmn) venoms incubated after electrophoresis, for $2 \mathrm{~h}$ at $37^{\circ} \mathrm{C}$. MWM-molecular weight markers (MW) in kDa. (C) Enzymatic activity of $10 \mu \mathrm{g}$ of bee venom phospholipase (BPLA2) as a positive control and $100 \mathrm{ng}$ from $\mathrm{Ca}, \mathrm{Cp}$ and $\mathrm{Cmn}$ venoms. Small letters (a,b) show statistical differences (Tukey $p<0.05$ ) between samples, positive control was not compared. Red arrows show bands with PLA 2 activity, and red asterisk show bands not shared between the venoms.

\subsection{Zymography and Enzymatic Activity of Hyaluronidases}

The snake venom hyaluronidases (SVH) have been reported in a range from 33 to $110 \mathrm{kDa}$ [55]. The highest variability was observed in the range of 20 to 50. However, Ramírez et al. (1990) reported that these enzymes were absent in Cmn venom [22] and for $\mathrm{Cp}$ venom, they have been detected by RP-HPLC/MS [30], whereas no previous reports for hyaluronidases were found for Ca venom. In this study, Ca, Cp, and Cmn venoms exhibited SVH with different MWs ranging from 10 to $150 \mathrm{kDa}$ (Figure 7). Cp venom showed the highest activity (lower turbidity), followed by Ca and Cmn venoms. These activities were lower than the bovine testes hyaluronidase used as positive control. Snake 
venom hyaluronidases are known as dispersion factors, degrading hyaluronic acid of the extracellular matrix which can indirectly induce hemorrhaging and myotoxic damage related to SVMP and PLA respectively. They provoke a synergistic effect on tissue degradation and necrosis at the bite site; this component, however, has not been thoroughly studied $[55,56]$.

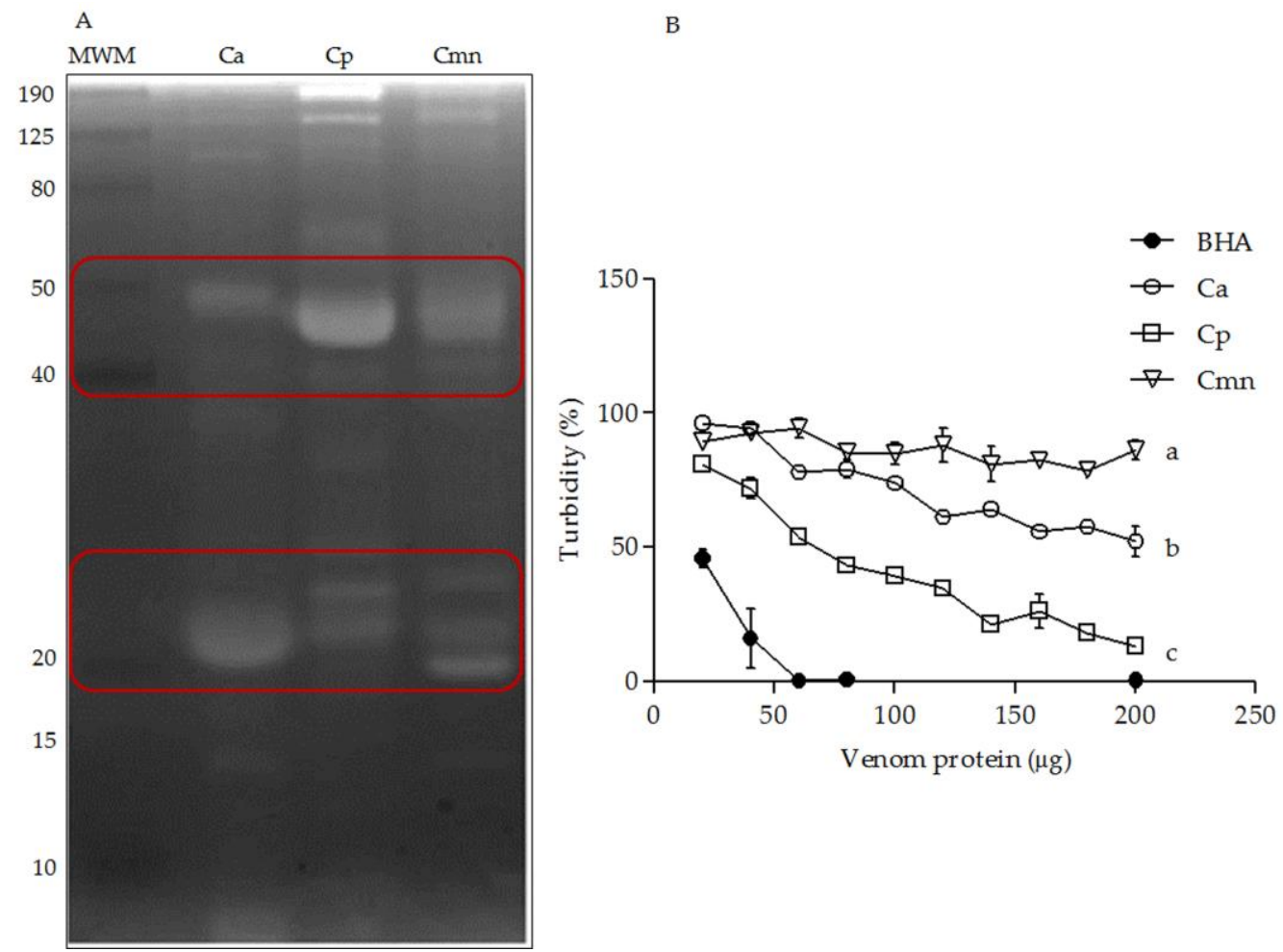

Figure 7. Hyaluronidase activity. (A) Zymography on SDS-PAGE co-polymerized with hyaluronic acid using $100 \mu \mathrm{g}$ venom protein, incubated after electrophoresis for $2.5 \mathrm{~h}$ at $37^{\circ} \mathrm{C}$. Molecular weight markers (MWM) in kDa. (B) Enzymatic activity using 5 to $50 \mu \mathrm{g}$ of C. aquilus (Ca), C. polystictus $(\mathrm{Cp})$, and C. molossus nigrescens ( $\mathrm{Cmn}$ ) venoms as well as hyaluronidase from bovine testes used as positive control (BHA). Red boxes show variability between the venoms. Small letters show statistical differences (Tukey $p<0.05$ ) between samples, positive control was not compared.

\subsection{RP-HPLC}

Fractionation of venoms from the three species by RP-HPLC showed similar elution profiles, however, the concentrations among them were different. Abundant peaks ( 10) between 40 and $55 \mathrm{~min}$ were found, where eluting times for proteins such as phospholipases $A_{2}$ (35-45 $\mathrm{min}$ ) [57], metalloproteases and hyaluronidases ( $\geq 50 \mathrm{~min}$ ) [58], have been reported. Peaks appearing at 20 and 30 min were less abundant ( 6), those peaks have similar eluting times to the previously reported for some serine proteases [59]. The last group of components, probably small peptides, eluted between 5 and $10 \mathrm{~min}$ [58]. Ca venom presented two peaks at $36 \mathrm{~min}$, that were absent in $\mathrm{Cp}$ and $\mathrm{Cmn}$ venoms, while $\mathrm{Cmn}$ venom showed two peaks at 50 and $51 \mathrm{~min}$ that were not shared with the other two species. At $5 \mathrm{~min}$, the most hydrophilic fractions were eluted in $\mathrm{Ca}$ and $\mathrm{Cmn}$ venoms. Cmn venom showed more variability, with more peaks eluting at 25,47 , and $50 \mathrm{~min}$, followed by $\mathrm{Ca}$ and $\mathrm{Cp}$ venoms with less eluted fractions, respectively. The eluting retention times are consistent with reported data for phosfolipases $A_{2}$, serine proteases (detected by zymography and enzymatic assays) and small peptides, however, the retention times for metalloproteinases and hylauronidases did not correspond with the retention times reported for other venoms, however, identification by enzymatic assays or MALDI-TOF Mass Spectrometry analysis are still needed, even though fractions were not detected after 60 min (Figure 8). 


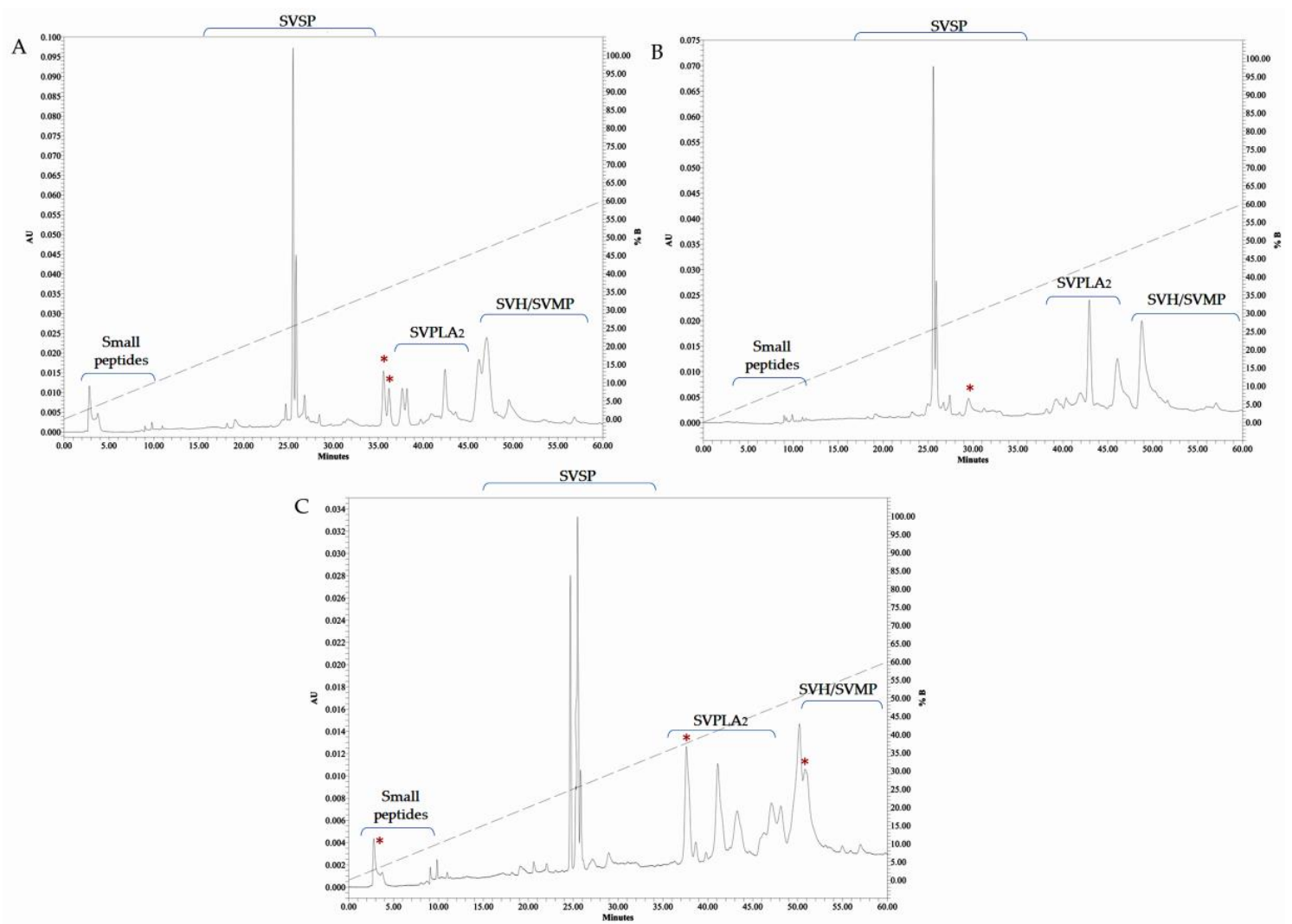

Figure 8. Venoms fractionation by RP-HPLC. Pooled crotalus venoms from (A) C. aquilus (Ca), (B) C. polystictus $(\mathrm{Cp})$ and $(\mathrm{C})$ C. molossus nigrescens $(\mathrm{Cmn})$. Red asterisk show peaks not shared between the venoms. Snake venom serine proteases (SVSP), snake venom metalloproteases, (SVMP) and snake venom hyaluronidases (SVH). Absorbance units (AU) at $280 \mathrm{~nm}$. Enzymatic activities were not determined, the family proposed for the enzymes are based on similarity of the elution profiles with reported data.

Cmn venom is considered highly hemorrhagic and hemotoxic [50,60]. Borja et al. (2018) reported that, using the Mexican antivenoms Antivipmyn ${ }^{\circledR}$ and Faboterapico polivalente antiviperino ${ }^{\circledR}$, this venom contains a large number of proteins with molecular weight below $20 \mathrm{kDa}$ (included crotamine-like myotoxins), that were weakly or not recognized by western blot in juvenile individuals, and they also reported problems for neutralizing lethality of adult snake venoms [23]. Our results for $\mathrm{Ca}$ and $\mathrm{Cp}$ venoms showed similar patterns of proteins by SDS-PAGE, zymography and enzymatic activities with respect to $\mathrm{Cmn}$ venom, therefore it could be possible that recognition by the same antivenoms would also be similar. The molecular weight for SVSP, SVMP and SVPLA 2 was similar to those observed by zymography.

\section{Materials and Methods}

\subsection{Venom Extraction}

The venom was obtained by manual extraction (milking) from four $\mathrm{Ca}$, four $\mathrm{Cp}$ (adults of at least $45 \mathrm{~cm}$ length) and nine $\mathrm{Cmn}$ (adults of at least $60 \mathrm{~cm}$ length), with no differentiation by sex. The snakes were housed at the Autonomous University of Querétaro (Queretaro, Mexico) Animal Resource Facility, which was regulated under the General Wildlife Law. The protocol was approved by the Bioethics Committee of the Natural Sciences Faculty. Venoms were pooled, lyophilized, and stored at $-70{ }^{\circ} \mathrm{C}$ until used. For all the analyses, the venom was dissolved in $\mathrm{dd}_{2} \mathrm{O}$ and protein concentration in venom was determined [61] using BSA as a standard (Sigma-Aldrich, St. Louis, MO, USA). 


\subsection{SDS-PAGE Protein Banding Pattern}

Twenty microgram of lyophilized venom protein was loaded into a 10 or $12 \%$ SDS-PAGE gel and electrophoresed in a Mini Protean II unit (Bio-Rad Hercules, CA, USA) or Hoefer MiniVE system (Hoefer, Holliston, MA, USA) under reducing (4\% of $\beta$-mercaptoethanol and 5 min at boiling water temperature) and non-reducing conditions [62]. Seven microliter of unstained (Thermo Fisher Scientific, Waltham, MA, USA) or pre-stained (Sigma-Aldrich) MWM standards was used for molecular weight estimation. The gel was stained with $0.1 \%$ Coomassie brilliant blue R-250 (Bio-Rad) in 40\% methanol and $10 \%$ acetic acid $(v / v)$ overnight, de-stained in $40 \%$ methanol and $10 \%$ glacial acetic acid $(v / v)$, and imaged on an HP Scanjet 4570c scanner.

\subsection{Zymography Assays}

\subsubsection{Serine Proteases Zymography}

Venom samples were analyzed for SVSP, after electrophoresis, using $100 \mu \mathrm{g}$ and $50 \mu \mathrm{g}$ protein venom, for chymotrypsin-like and trypsin-like activities. A cellulose membrane (Bio-Rad) previously embedded with the specific substrate, for each serine protease was placed on top of the gel, incubated at $37{ }^{\circ} \mathrm{C}$ for $2.5 \mathrm{~h}$ (or until yellow bands in the gel were observed) and washed with $0.1 \% \mathrm{NaNO}_{3}, 0.5 \%\left(\mathrm{NH}_{4}\right)_{2} \mathrm{SO}_{4}$ in $1 \mathrm{M} \mathrm{HCl}$ and with $0.05 \% \mathrm{~N}-1$-naphthylethylenediamine in $47.5 \%$ ethanol for periods of $5 \mathrm{~min}$ each. After the incubation time, the protein gel was stained/de-stained according to the method previously described. The substrates were prepared using $20 \mathrm{mM}$ SAAPFpNA (N-Succinyl-Alanine-Alanine-Proline-Phenylalanine-p-nitroanilide, Sigma-Aldrich) for chymotrypsin-like enzymes and 20 mM BApNA (N-Succinyl-Arginine-p-nitroanilide, Sigma-Aldrich) for trypsin-like enzymes $[63,64]$.

\subsubsection{Metalloproteases Zymography}

Ten microgram of venom protein samples was run on polyacrylamide gels co-polymerized with $0.12 \%$ gelatin (Sigma-Aldrich) as a substrate [65]. The gel was washed in a $2.5 \%$ Triton X100 solution for $1 \mathrm{~h}$ and later for $30 \mathrm{~min}$ in a $0.05 \mathrm{M}$ Tris- $\mathrm{HCl}(\mathrm{pH} 7.4)$ buffer and finally incubated for 2-3 $\mathrm{h}$ in a $0.2 \mathrm{M} \mathrm{NaCl}, 0.005 \mathrm{M} \mathrm{CaCl}_{2}$, Triton X-100 0.002\% (v/v), 0.001 M cysteine and 0.05 M Tris- $\mathrm{HCl}(\mathrm{pH} 8)$ buffer. To confirm the presence of metalloproteases, venom samples were incubated for 30 min with EDTA (Bio-Rad) at 10, 50, and $100 \mathrm{mM}$ concentrations in a buffer solution without $\mathrm{CaCl}_{2}$.

\subsection{3. $\mathrm{PLA}_{2}$ Zymography}

After $20 \mu \mathrm{g}$ of venom protein samples were run in a 10\% SDS-PAGE gel under non-reducing conditions, the gel was washed for $1 \mathrm{~h}$ with Triton X-100 2.0\% (v/v) and Tris-HCl 0.5 M, pH 7.4 buffer. The gel was subsequently washed for $30 \mathrm{~min}$ in a buffer with $140 \mathrm{mM} \mathrm{NaCl}, 2.5 \mathrm{mM} \mathrm{CaCl} 2$ and $50 \mathrm{mM}$ Tris- $\mathrm{HCl}$ (pH 7.4) and then incubated for $2.5 \mathrm{~h}$ at $37^{\circ} \mathrm{C}$ on a $1 \%$ agarose (Sigma-Aldrich) gel co-polymerized with a solution containing $50 \mathrm{mM}$ Tris- $\mathrm{HCl}(\mathrm{pH} 7.4), 140 \mathrm{mM} \mathrm{NaCl}, 2.5 \mathrm{mM} \mathrm{CaCl} \mathrm{ma}_{2}$ and $2 \%$ egg yolk. The light zones indicated the presence of PLA 2 [66].

\subsubsection{Hyaluronidases Zymography}

A 10\% SDS-PAGE gel was co-polymerized with hyaluronic acid (Sigma-Aldrich) and then $100 \mu \mathrm{g}$ of venom protein were analyzed via non-reducing electrophoresis. The gel was washed $30 \mathrm{~min}$ with a $0.2 \mathrm{M}$ sodium acetate ( $\mathrm{pH}$ 6), $0.15 \mathrm{M} \mathrm{NaCl}$ and 2.5\% (v/v) X-100 Triton buffer solution and subsequently incubated from 2.5 to $3 \mathrm{~h}$ at $37^{\circ} \mathrm{C}$ in the same buffer solution without Triton. The gel was stained with alcian blue dye (Sigma-Aldrich) at $0.5 \%(w / v)$ and subsequently de-stained with a solution containing $40 \%$ methanol and $10 \%$ acetic acid [67]. 


\subsection{Enzyme Assays}

\subsubsection{Serine Protease Activities}

The amidolytic activity was determined using $50 \mu \mathrm{g}$ of venom protein, to measure trypsin-like, chymotrypsin-like, and elastase-like activities using BApNA, SAAPFpNA, and $10 \mathrm{mM}$ N-Methoxysuccinyl-Ala-Ala-Pro-Val p-nitroanilide (Sigma-Aldrich) in dimethylsulfoxide as substrates, respectively. The mixture was brought to a final volume of $120 \mu \mathrm{L}$ with $0.1 \mathrm{M}$ Tris (pH 8) buffer and $10 \mu \mathrm{L}$ of substrate was added to start the reaction. Activity was determined by the release of p-nitroanilide that absorbs at $405 \mathrm{~nm}$, reporting as activity units $(\mathrm{AU}) / \mathrm{min} / \mu \mathrm{g}$ venom protein. One AU corresponded to an increase of absorbance of 0.01 at $405 \mathrm{~nm}$ [68]. Analyses were done in triplicate. In each case, bovine chymotrypsin, bovine trypsin and porcine elastase (Sigma-Aldrich) were used as positive controls.

\subsubsection{Proteolytic Activity}

Proteolytic activity was assayed according to Gutiérrez et al. (2008) and Ponce et al. (2007) [69,70] with modifications. Briefly, $100 \mu \mathrm{g}$ of venom protein and $500 \mu \mathrm{L}$ of $2 \%(w / v)$ casein (Sigma-Aldrich) were diluted in $0.1 \mathrm{mM}$ Tris- $\mathrm{HCl}(\mathrm{pH} 7.4)$ and $0.15 \mathrm{M} \mathrm{NaCl}$ buffer. After $2.5 \mathrm{~h}$ of incubation at $37^{\circ} \mathrm{C}$, the reaction was stopped by adding $500 \mu \mathrm{L}$ of $5 \%(w / v)$ trichloroacetic acid (TCA) at $37^{\circ} \mathrm{C}$ for $30 \mathrm{~min}$ at room temperature. The mixture was centrifuged at 12,000 $\mathrm{g}$ for $15 \mathrm{~min}$, and the casein hydrolysis was measured at $280 \mathrm{~nm}$. Water was used as a negative control. Venom samples were incubated with $50 \mathrm{mM}$ EDTA (Sigma-Aldrich) for $30 \mathrm{~min}$ before casein was added, to confirm the proteolytic activity of metalloproteases. The proteolytic activity was reported as activity units (AU)/ $\mu \mathrm{g}$ venom protein where one activity unit corresponded to an increase of absorbance of 0.01 at $280 \mathrm{~nm}$.

\subsubsection{Phospholipase $A_{2}$ Activity}

Phospholipase activity of $100 \mathrm{ng}$ of venom protein was analyzed by a colorimetric assay using the Cayman Chemical kit (Ann Arbor, MI, USA, catalogue number 765001). The assay used 1,2-dithio diheptanoyl phosphatidylcholine analogue as substrate. The free thiols generated by hydrolysis of the thioester bonds were detected using DTNB [(5,5'-dithio-bis- (2-nitrobenzoic acid)]. The increase in absorbance was measured in a spectrophotometer (Benchmark Plus, Bio-Rad, USA) at $414 \mathrm{~nm}$ every minute for $10 \mathrm{~min}$. PLA 2 of bee venom was used as a positive control. The enzymatic activity was expressed in substrate $\mu \mathrm{mol}$ hydrolyzed $/ \mathrm{min} / \mu \mathrm{g}$ protein.

\subsubsection{Hyaluronidase Activity}

Venom protein concentrations ranging from 20 to $200 \mu \mathrm{g}$ were mixed with $100 \mu \mathrm{L}$ of $0.2 \mathrm{M}$ sodium acetate (pH 6), $0.15 \mathrm{M} \mathrm{NaCl}$ buffer, and $100 \mu \mathrm{L}$ of $1 \mathrm{mg} / \mathrm{mL}$ solution of Streptococcus equi hyaluronic acid (Sigma-Aldrich) as a substrate for a final volume of $250 \mu \mathrm{L}$. After $15 \mathrm{~min}$ incubation at $37^{\circ} \mathrm{C}$, the reaction was stopped by adding $1 \mathrm{~mL}$ of $2.5 \%$ hexadecyl trimethyl ammonium bromide in $2 \% \mathrm{NaOH}$ for $30 \mathrm{~min}$ at room temperature. Turbidity was determined at $400 \mathrm{~nm}$ in a plate reader using a spectrophotometer (Benchmark Plus, Bio-Rad, USA). Bovine testes type IV-S hyaluronidase (Sigma-Aldrich) was used as control [71].

\subsection{RP-HPLC}

For RP-HPLC analysis, $200 \mu \mathrm{g}$ of venom protein from pooled venoms of $\mathrm{Ca}, \mathrm{Cp}$ and $\mathrm{Cmn}$ were used, by using a C18 symmetry column $(150 \times 4.6 \mathrm{~mm}$. Particle size: $3.5 \mu \mathrm{m})$ equilibrated with solution A $\left(\mathrm{H}_{2} \mathrm{O}\right.$ at $0.1 \%$ with TFA), using an Agilent 1200 chromatograph. Elution was performed at $1 \mathrm{~mL} / \mathrm{min}$ using a gradient towards solution $\mathrm{B}\left(\mathrm{CH}_{3} \mathrm{CN}\right.$ at $0.1 \%$ with TFA) as follows: $0 \% \mathrm{~B}$ by $5 \mathrm{~min}, 0 \%-60 \% \mathrm{~B}$ over $60 \mathrm{~min}$. Absorbance was monitored at $280 \mathrm{~nm}$. 


\subsection{Statistical Analysis}

To evaluate differences between venom enzymatic activities, data were analyzed using the GraphPad Prism V5.0 software by ANOVA (Tukey $p<0.05$ ).

\section{Conclusions}

Analysis of three different Crotalus species: Crotalus aquilus (Ca), Crotalus polystictus (Cp) and Crotalus molossus nigrescens ( $\mathrm{Cmn}$ ) Crotalus snake venoms showed differences between the quality and quantity of the studied enzymes. Some of the proteases found in the studied species showed molecular weights not previously reported that also differed among the analyzed venoms, pointing to the importance of studying the wide diversity composition between Crotalus species. Some of these differences of the observed bands could correspond to oligomeric forms of enzymes previously reported present in other snake venoms, which could also explain the absence in the zymography of the $25 \mathrm{kDa}$ SVMP reported. Our results show that $\mathrm{Ca}, \mathrm{Cp}$ and $\mathrm{Cmn}$ venoms are mainly hemotoxic with the main groups of enzyme families usually found in Viperidae venom: metalloproteases, serine proteases, phospholipases A2, and hyaluronidases, in high quantities and a variable number of peptides, probably crotamine-like myotoxins. These enzymes are present in different proportions and different enzymatic activities, depending on the species. Ca venom, showed the highest SVMP activity, with a greater number of bands of high molecular weight, whereas Cp venom showed the highest activities for SVSP (trypsin and chymotrypsin-like) and SVH proteases; Cmn venom presented similar activity level for SVSP activity (elastase-like) and just higher activity of PLA2 than Cp venom, but with less abundance of high molecular weight SVMP. The PLA2 enzymatic activity was highly active in all the venoms. In Cmn, SVSP activity, and also some small proteins and peptides (lower than $20 \mathrm{kDa}$ ) with low recognition by two antivenoms, plays an important role in venom toxicity. The enzymatic activities as by zymography and RP-HPLC data showed similar patterns between venoms. We suggest that $C a$ and $C p$ venoms could have a similar high hemorrhagic, hemotoxic and hemolytic effects as has been reported for $\mathrm{Cmn}$. Finally, the presence of a wide range of hydrolytic enzymes in the studied venoms may play an important role in their toxic effect. Knowledge of venom variability could be useful in developing more effective strategies in anti-venom therapy. Besides, characterization of the different proteases could also be of importance for their potential biotechnological application. Further work will determine the molecular identity of the main enzymes for each snake venom in order to have a better knowledge of therapeutic antidotes.

Author Contributions: O.R.-P. performed all the biochemical assays and data analyses. T.G.-G., A.B.-L., J.A.G.-A., J.L.C.-G., C.S. and L.F.D.-P. supervised the methodology. M.S.C.-P. collaborated with the snake maintenance and venom extraction. T.G.-G., A.B.-L., J.A.G.-A. and M.S.C.-P. contributed with various resources. T.G.-G. and A.B.-L. codirected the work and helped to obtain financial support for the project. All co-authors worked on the data analyses, interpretation, and discussion of the paper, and they approved the final submission. O.R.-P., A.B.-L. and T.G.-G. wrote, reviewed, and edited the manuscript.

Funding: This study was supported by CONACYT (ORP fellowship), FOPER-UAQ and PFCE 2017. Publication charges were provided by PRODEP 2019.

Acknowledgments: We thank Oscar Antonio Rayas Estrada for the Cp venom samples, Elizabeth Mendiola-Olaya for her technical support, and Carolyn Smith of Peace Corps Response for her useful advice when reviewing the manuscript. This work received support from Luis Aguilar, Alejandro de León, Carlos Flores, and Jair García from the Laboratorio Nacional de Visualización Científica Avanzada UNAM-UAQ.

Conflicts of Interest: The authors declare no conflict of interest.

\section{References}

1. Kasturiratne, A.; Wickremasinghe, A.R.; De Silva, N.; Gunawardena, N.K.; Pathmeswaran, A.; Premaratna, R.; Savioli, L.; Lalloo, D.G.; De Silva, H.J. The global burden of snakebite: A literature analysis and modelling based on regional estimates of envenoming and deaths. PLoS Med. 2008, 5, 1591-1604. [CrossRef] [PubMed]

2. Chippaux, J.P. Snake-bites: Appraisal of the global situation. Bull. World Health Organ. 1998, 76, 515-524. [PubMed] 
3. Fry, B.G. Snakebite: When the Human Touch Becomes a Bad Touch. Toxins (Basel) 2018, 10, 170. [CrossRef] [PubMed]

4. Peterson, M.E. Snake Bite: Pit Vipers. Clin. Tech. Small Anim. Pract. 2006, 21, 174-182. [CrossRef] [PubMed]

5. WHO. Progress in the Characterization of Venoms and Standardization of Antivenoms; WHO Offset Publ.; World Health Organization: Geneva, Switzerland, 1981; pp. 1-44.

6. Winkel, K.; Hawdon, G.; Ashby, M.K. Venomous bites and stings. Hazard 1998, 35, 1-16.

7. Trape, J.F.; Pison, G.; Guyavarch, E.; Mane, Y. High mortality from snakebite in south-eastern Senegal. Trans. R. Soc. Trop. Med. Hyg. 2001, 95, 420-423. [CrossRef]

8. Braud, S.; Bon, C.; Wisner, A. Snake venom proteins acting on hemostasis. Biochimie 2000, 82, 851-859. [CrossRef]

9. Xiong, S.; Huang, C. Synergistic strategies of predominant toxins in snake venoms. Toxicol. Lett. 2018, 287, 142-154. [CrossRef]

10. Bordon, K.C.F.; Perino, M.G.; Giglio, J.R.; Arantes, E.C. Isolation, enzymatic characterization and antiedematogenic activity of the first reported rattlesnake hyaluronidase from Crotalus durissus terrificus venom. Biochimie 2012, 94, 2740-2748. [CrossRef] [PubMed]

11. Cevallos, M.A.; Navarro-Duque, C.; Varela-Julia, M.; Alagon, A.C. Molecular mass determination and assay of venom hyaluronidases by sodium dodecyl sulfate-polyacrylamide gel electrophoresis. Toxicon 1992, 30, 925-930. [CrossRef]

12. Sartim, M.A.; Cezarette, G.N.; Jacob-Ferreira, A.L.; Frantz, F.G.; Faccioli, L.H.; Sampaio, S.V. Disseminated intravascular coagulation caused by moojenactivase, a procoagulant snake venom metalloprotease. Int. J. Biol. Macromol. 2017, 103, 1077-1086. [CrossRef]

13. Laraba-Djebari, F.; Chérifi, F. Pathophysiological and Pharmacological Effects of Snake Venom Components: Molecular Targets. J. Clin. Toxicol. 2014, 4, 190.

14. Sanhajariya, S.; Duffull, S.B.; Isbister, G.K. Pharmacokinetics of snake venom. Toxins (Basel) 2018, 10, 73. [CrossRef]

15. Angulo, Y.; Lomonte, B. Biochemistry and toxicology of toxins purified from the venom of the snake Bothrops asper. Toxicon 2009, 54, 949-957. [CrossRef]

16. Sanchez, E.F.; Flores-Ortiz, R.J.; Alvarenga, V.G.; Eble, J.A. Direct fibrinolytic snake venom metalloproteinases affecting hemostasis: Structural, biochemical features and therapeutic potential. Toxins (Basel) 2017, 9, 392. [CrossRef]

17. Brahma, R.K.; McCleary, R.J.R.; Kini, R.M.; Doley, R. Venom gland transcriptomics for identifying, cataloging, and characterizing venom proteins in snakes. Toxicon 2015, 93, 1-10. [CrossRef]

18. Campbell, J.A.; Lamar, W.W. The venomous reptiles of the western hemisphere. Comstock Books Herpetol. 2004.

19. McCranie, J.R. Crotalus polystictus. Soc. Study Amphib. Reptil. 1976, 180, 1-2.

20. Campbell, J.A.; Lamar, W.W. The Venomous Reptiles of Latin America. Q. Rev. Biol. 1989, 65, 516-517.

21. Mackessy, S.P. The Field of Reptile Toxinology, Snakes, Lizards, and Their Venom. In Handbook of Venoms and Toxins of Reptiles; CRC Press: Boca Raton, FL, USA, 2010; pp. 3-23.

22. Ramírez, G.A.; Fletcher, P.L.; Possani, L.D. Characterization of the venom from Crotalus molossus nigrescens Gloyd (black tail rattlesnake): Isolation of two proteases. Toxicon 1990, 28, 285-297. [CrossRef]

23. Borja, M.; Neri-Castro, E.; Pérez-Morales, R.; Strickland, J.; Ponce-López, R.; Parkinson, C.; Espinosa-Fematt, J.; Sáenz-Mata, J.; Flores-Martínez, E.; Alagón, A.; et al. Ontogenetic Change in the Venom of Mexican Black-Tailed Rattlesnakes (Crotalus molossus nigrescens). Toxins (Basel) 2018, 10, 501. [CrossRef]

24. Mackessy, S.; Leroy, J.; Mociño-Deloya, E.; Setser, K.; Bryson, R.; Saviola, A. Venom Ontogeny in the Mexican Lance-Headed Rattlesnake (Crotalus polystictus). Toxins (Basel) 2018, 10, 271. [CrossRef] [PubMed]

25. Rivas, E.; Neri-Castro, E.; Bénard-Valle, M.; Hernánez-Dávila, A.I.; Zamudio, F.; Alagón, A. General characterization of the venoms from two species of rattlesnakes and an intergrade population (C. lepidus $\mathrm{x}$ aquilus) from Aguascalientes and Zacatecas, Mexico. Toxicon 2017, 138, 191-195. [CrossRef]

26. Roy, K.; Dey, S.; Uddin, M.K.; Barua, R.; Hossain, M.T. Extracellular Pectinase from a Novel Bacterium Chryseobacterium indologenes Strain SD and Its Application in Fruit Juice Clarification. Enzyme Res. 2018, 2018, 3859752. [CrossRef] [PubMed]

27. Moss, D.W. Accuracy, precision, and quality control of enzyme Assays. J. Clin. Pathol. 1970, 4, 22-30. [CrossRef] 
28. Serrano, S.M.T.; Shannon, J.D.; Wang, D.; Camargo, A.C.M.; Fox, J.W. A multifaceted analysis of viperid snake venoms by two-dimensional gel electrophoresis: An approach to understanding venom proteomics. Proteomics 2005, 5, 501-510. [CrossRef]

29. Chippaux, J.P.; Williams, V.; White, J. Snake venom variability: Methods of study, results and interpretation. Toxicon 1991, 29, 1279-1303. [CrossRef]

30. Izidoro, L.F.M.; Sobrinho, J.C.; Mendes, M.M.; Costa, T.R.; Grabner, A.N.; Rodrigues, V.M.; Da Silva, S.L.; Zanchi, F.B.; Zuliani, J.P.; Fernandes, C.F.C.; et al. Snake venom L-amino acid oxidases: Trends in pharmacology and biochemistry. Biomed Res. Int. 2014, 2014, 196754. [CrossRef]

31. Costa, T.R.; Burin, S.M.; Menaldo, D.L.; de Castro, F.A.; Sampaio, S.V. Snake venom L-amino acid oxidases: An overview on their antitumor effects. J. Venom. Anim. Toxins Incl. Trop. Dis. 2014, 20, 23. [CrossRef] [PubMed]

32. Serrano, S.M.T. The long road of research on snake venom serine proteinases. Toxicon 2013, 62, $19-26$. [CrossRef] [PubMed]

33. Serrano, S.M.T.; Maroun, R.C. Snake venom serine proteinases: Sequence homology vs. substrate specificity, a paradox to be solved. Toxicon 2005, 45, 1115-1132. [CrossRef]

34. Castro, H.C.; Zingali, R.B.; Albuquerque, M.G.; Pujol-Luz, M.; Rodrigues, C.R. Snake venom thrombin-like enzymes: From reptilase to now. Cell. Mol. Life Sci. 2004, 61, 843-856. [CrossRef]

35. Khan, A.R.; James, M.N.G. Molecular mechanisms for the conversion of zymogens to active proteolytic enzymes. Protein Sci. 1998, 7, 815-836. [CrossRef]

36. Wagner, O.F.; Bergmann, I.; Binder, B.R. Chromogenic substrate autography: A method for detection, characterization, and quantitative measurement of serine proteases after sodium dodecyl sulfate-polyacrylamide gel electrophoresis or isoelectric focusing in polyacrylamide gels. Anal. Biochem. 1985, 151, 7-12. [CrossRef]

37. Baramova, E.N.; Shannon, J.D.; Bjarnason, J.B.; Fox, J.W. Degradation of extracellular matrix proteins by hemorrhagic metalloproteinases. Arch. Biochem. Biophys. 1989, 275, 63-71. [CrossRef]

38. Bjarnason, J.B.; Fox, J.W. Hemorrhagic metalloproteinases from snake venoms. Pharmacol. Ther. 1994, 62, 325-372. [CrossRef]

39. Krogdahl, A.; Holm, H. Pancreatic proteinases from man, trout, rat, pig, cow, chicken, mink and fox. Enzyme activities and inhibition by soybean and lima bean proteinase inhibitors. Comp. Biochem. Physiol. B 1983, 74, 403-409. [CrossRef]

40. Fox, J.W.; Serrano, S.M.T. Insights into and speculations about snake venom metalloproteinase (SVMP) synthesis, folding and disulfide bond formation and their contribution to venom complexity. FEBS J. 2008, 275, 3016-3030. [CrossRef]

41. Zaqueo, K.D.; Kayano, A.M.; Simões-Silva, R.; Moreira-Dill, L.S.; Fernandes, C.F.C.; Fuly, A.L.; Maltarollo, V.G.; Honório, K.M.; Da Silva, S.L.; Acosta, G.; et al. Isolation and biochemical characterization of a new thrombin-like serine protease from Bothrops pirajai snake venom. Biomed. Res. Int. 2014, 2014, 1-13. [CrossRef]

42. Sánchez, E.E.; Soliz, L.A.; Ramírez, M.S.; Pérez, J.C. Partial characterization of a basic protein from Crotalus molossus molossus (northern blacktail rattlesnake) venom and production of a monoclonal antibody. Toxicon 2001, 39, 523-537. [CrossRef]

43. Chen, T.; Rael, E.D. Purification of M5, a fibrinolytic proteinase from Crotalus molossus molossus venom that attacks complement. Int. J. Biochem. Cell Biol. 1997, 29, 789-799. [CrossRef]

44. Mackessy, S.P. Thrombin-like enzymes in snake venoms. In Toxins and Hemostasis: From Bench to Bedside; Springer: Dordrecht, The Netherlands, 2010; pp. 519-557.

45. Kini, R.M.; Koh, C.Y. Metalloproteases affecting blood coagulation, fibrinolysis and platelet aggregation from snake venoms: Definition and nomenclature of interaction sites. Toxins (Basel) 2016, 8, 284. [CrossRef]

46. Doley, R.; Kini, R.M. Protein complexes in snake venom. Cell. Mol. Life Sci. 2009, 66, 2851-2871. [CrossRef]

47. Gutiérrez, M.J.; Rucavado, A.; Escalante, T. Snake Venom Metalloproteinases. In Handbook of Venoms and Toxins of Reptiles; CRC Press: Boca Raton, FL, USA, 2010; pp. 115-138.

48. Gutiérrez, M.J. Snakebite Envenomation in Central America. In Handbook of Venoms and Toxins of Reptiles; Mackessy, S.P., Ed.; CRC Press/Taylor \& Francis: Boca Raton, FL, USA, 2010; pp. 491-507. 
49. Macias-Rodríguez, E.F.; Martínez-Martínez, A.; Gatica-Colima, A.; Bojórquez-Rangel, G.; Plenge-Tellechea, L.F. Análisis comparativo de la actividad hemolítica entre las subespecies Crotalus molossus y Crotalus molossus nigrescens. Rev. Bio Ciencias 2014, 2, 302-312.

50. Meléndez-Martínez, D.; Macías-Rodríguez, E.; Vázquez-Briones, R.; López-Vera, E.; Cruz-Pérez, M.S.; Vargas-Caraveo, A.; Gatica-Colima, A.; Plenge-Tellechea, L.F. In vitro hemotoxic, $\alpha$-neurotoxic and vasculotoxic effects of the Mexican black-tailed rattlesnake (Crotalus molossus nigrescens) venom. J. Venom Res. 2017, 8, 1-8.

51. Ferlan, I.; Ferlan, A.; Capel, M.S.; Russell, F.E. Isolation and characterization of two phospholipases from Crotalus molossus molossus venom. Toxicon 1983, 21, 129-132. [CrossRef]

52. Tsai, I.H.; Chen, Y.H.; Wang, Y.M.; Tu, M.C.; Tu, A.T. Purification, sequencing, and phylogenetic analyses of novel Lys-49 phospholipases A2from the venoms of rattlesnakes and other pit vipers. Arch. Biochem. Biophys. 2001, 394, 236-244. [CrossRef]

53. Zhou, X.; Manjunatha Kini, R.; Doley, R. Snake Venom Phospholipase A2 Enzymes. In Handbook of Venoms and Toxins of Reptiles; Mackessy, S.P., Ed.; CRC Press/Taylor \& Francis: Boca Raton, FL, USA, 2009; pp. 173-205. ISBN 978-0-8493-9165-1.

54. Oliveira, A.; Bleicher, L.; Schrago, C.G.; Silva Junior, F.P. Conservation analysis and decomposition of residue correlation networks in the phospholipase A2 superfamily (PLA2s): Insights into the structure-function relationships of snake venom toxins. Toxicon 2018, 146, 50-60. [CrossRef]

55. Kemparaju, K.; Girish, K.S.; Nagaraju, S. Hyaluronidases, a Neglected Class of Glycosidases from Snake Venom. In Handbook of Venoms and Toxins of Reptiles; Mackessy, S.P., Ed.; CRC Press/Taylor \& Francis: Boca Raton, FL, USA, 2009; pp. 237-258.

56. Girish, K.S.; Shashidharamurthy, R.; Nagaraju, S.; Gowda, T.V.; Kemparaju, K. Isolation and characterization of hyaluronidase a "spreading factor" from Indian cobra (Naja naja) venom. Biochimie 2004, 86, 193-202. [CrossRef]

57. Marangoni, F.A.; Ponce-Soto, L.A.; Marangoni, S.; Landucci, E.C.T. Unmasking snake venom of Bothrops leucurus: Purification and pharmacological and structural characterization of new PLA2 Bleu TX-III. Biomed Res. Int. 2013, 2013, 941467. [CrossRef]

58. Lomonte, B.; Calvete, J.J. Strategies in 'snake venomics' aiming at an integrative view of compositional, functional, and immunological characteristics of venoms. J. Venom. Anim. Toxins Incl. Trop. Dis. 2017, 23, 26. [CrossRef] [PubMed]

59. Menaldo, D.L.; Bernardes, C.P.; Santos-Filho, N.A.; Moura, L.d.A.; Fuly, A.L.; Arantes, E.C.; Sampaio, S.V. Biochemical characterization and comparative analysis of two distinct serine proteases from Bothrops pirajai snake venom. Biochimie 2012, 94, 2545-2558. [CrossRef] [PubMed]

60. Munekiyo, S.M.; Mackessy, S.P. Effects of Temperature and Storage Conditions on the Electrophoretic, Toxic and Enzymatic Stability of Venom Components. Comp. Biochem. Physiol. Part B Biochem. Mol. Biol. 1998, 119, 119-127. [CrossRef]

61. Bradford, M.M. A rapid and sensitive method for the quantitation of microgram quantities of protein utilizing the principle of protein-dye binding. Anal. Biochem. 1976, 72, 248-254. [CrossRef]

62. Laemmli, U.K. Cleavage of structural proteins during the assembly of the head of bacteriophage T4. Nature 1970, 227, 680-685. [CrossRef]

63. Ohlsson, B.G.; Weström, B.R.; Karlsson, B.W. Enzymoblotting: A method for localizing proteinases and their zymogens using para-nitroanilide substrates after agarose gel electrophoresis and transfer to nitrocellulose. Anal. Biochem. 1986, 152, 239-244. [CrossRef]

64. Vinokurov, K.S.; Oppert, B.; Elpidina, E.N. Notes \& Tips An overlay technique for postelectrophoretic analysis of proteinase spectra in complex mixtures using p-nitroanilide substrates. Anal. Biochem. 2005, 337, 164-166. [PubMed]

65. Rice, K.; Peralta, R.; Bast, D.; De Azavedo, J.; McGavin, M.J. Description of staphylococcus serine protease (ssp) operon in Staphylococcus aureus and nonpolar inactivation of sspA-encoded serine protease. Infect. Immun. 2001, 69, 159-169. [CrossRef] [PubMed]

66. Rossignol, G.; Merieau, A.; Guerillon, J.; Veron, W.; Lesouhaitier, O.; Feuilloley, M.G.J.; Orange, N. Involvement of a phospholipase $\mathrm{C}$ in the hemolytic activity of a clinical strain of Pseudomonas fluorescens. BMC Microbiol. 2008, 8, 189. [CrossRef] [PubMed] 
67. Guntenhöner, M.W.; Pogrel, M.A.; Stern, R. A substrate-gel assay for hyaluronidase activity. Matrix 1992, 12, 388-396. [CrossRef]

68. Erlanger, B.F.; Kokowsky, N.; Cohen, W. The preparation and properties of two new chromogenic substrates of trypsin. Arch. Biochem. Biophys. 1961, 95, 271-278. [CrossRef]

69. Gutiérrez, J.M.; Sanz, L.; Escolano, J.; Fernández, J.; Lomonte, B.; Angulo, Y.; Rucavado, A.; Warrell, D.A.; Calvete, J.J. Snake venomics of the lesser antillean pit vipers bothrops caribbaeus and Bothrops lanceolatus: Correlation with toxicological activities and immunoreactivity of a heterologous antivenom. J. Proteome Res. 2008, 7, 4396-4408. [CrossRef]

70. Ponce-Soto, L.A.; Bonfim, V.L.; Novello, J.C.; Navarro Oviedo, R.; Yarlequé Chocas, A.; Marangoni, S. Isolation and characterization of a serine protease, Ba III-4, from Peruvian Bothrops atrox venom. Protein J. 2007, 26, 387-394. [CrossRef]

71. Di Ferrante, N. Turbidimetric measurement of acid mucopolysaccharides and hyaluronidase activity. J. Biol. Chem. 1956, 220, 303-306.

Sample Availability: Snake venoms samples are available from the authors.

(C) 2019 by the authors. Licensee MDPI, Basel, Switzerland. This article is an open access article distributed under the terms and conditions of the Creative Commons Attribution (CC BY) license (http://creativecommons.org/licenses/by/4.0/). 